\title{
China's foray into African security and the question of non-interference
}

\author{
By Festus Aubyn*
}

Researcher

Kofi Annan International Peacekeeping Training Centre, Ghana

\begin{abstract}
Historically, China-Africa relations have been dominated by economic rationales and the policy of non-interference has restricted its engagement in African peace and security. However, in the past two decades, Beijing's contribution towards African peace and security has dramatically expanded. In this paper, we seek to ascertain the factors behind China's growing role in African security at the multilateral, continental, sub-regional and national levels and how it has impacted on China's foreign policy of non-interference. The paper argues that although the policy of non-interference was a workable model in the 1950s, it is not in sync with current realities. Therefore, Beijing needs to rethink its policy of noninterference in order to protect its economic investments and political interests, which have come under threat in recent years. Undeniably, the increasing role of China also has important implications for the policy and interests of other external actors on the African continent such as the United States of America, the European
\end{abstract}

*Festus Aubyn is a Researcher with the Training for Peace Programme (TfP) at the Kofi Annan International Peacekeeping Training Centre (KAIPTC), Ghana and a Doctoral Candidate in Peace and Conflict Studies at the University of Ibadan, Nigeria 


\section{AFRICAN \\ EAST-ASIAN \\ AFFAIRS \\ THE CHINA MONITOR}

Union (EU), India, and Canada. To this end, the paper concludes by exploring ways in which China can collaborate and coordinate its activities with these actors to foster sustainable peace and security on the African continent.

\section{Introduction}

As China-Africa relations have grown rapidly in the past two decades, China's engagement with the continent has evolved from being mostly economic to now including the spheres of peace and security. Particularly since the beginning of the $21 \mathrm{st}$ Century, Beijing has become increasingly engaged in the prevention, mediation and resolution of African security dilemmas, contrasting sharply with its passive posture circa the 1970s and 1980s. This paper examines the security dimension of ChinaAfrica relations in the past two decades and how it has impacted on its foreign policy of non-interference. To put the study into context, the paper begins with a brief overview of China's relation with Africa since the post-independence period. Next, the key factors shaping Chinese interests in African security are explored. China-Africa relations have been dominated historically by economic rationales; the policy of noninterference has, until the 1990s, restricted China's engagement in global peace and security. For that reason, we seek to ascertain the factors behind China's increasing role in African peace and security. The subsequent section examines the role or contributions of China to African security at four levels: the multilateral level at the United Nations (UN); the Continental level of the African Union (AU); the Subregional level of the Regional Economic Communities (RECs); and China's role at the national level with individual African countries. Increasingly, China's growing role in African security issues has challenged or put strains on its long-established policy of non-interference, to the extent that many scholars have questioned whether it is possible for the policy to be maintained today. In this regard, the paper also interrogates China's increasing role in African security and how it has impacted on its policy of non-interference, particularly taking cognizance of Beijing's recent approach to the conflicts in Sudan and Libya. 
The paper argues that the policy of non-interference is not in sync with contemporary realities or challenges of conflicts and political instability in Africa. There is no doubt that the policy was a workable model in the 1950s and beyond, when China's economic interaction with Africa and the rest of the world was at a minimum. With growing Chinese investments, political interest and power on the global stage, we argue that Beijing needs to foster sustainable peace and stability on the continent as well as re-think its non-interference policy in order to protect its interests, which have come under threat in countries such as Libya, Sudan and Nigeria. Lastly, the heightened engagement in Africa by China undoubtedly has important implications for the policies and interest of other external actors, such as the United States of America, the European Union (EU) and emerging powers like India, Brazil, Canada, Australia and Russia. In this regard, we also explore areas where both China and other external actors differ in their approach to the resolution of African security challenges and where they can collaborate and coordinate their activities to foster sustainable peace and security in Africa.

\section{China-Africa relations: a brief historical overview}

China and Africa first came into contact during the 10th Century when the Egyptian city of Alexandria started trading with China. However, it was only during the Bandung Conference on Non-Alignment ${ }^{1}$ in April 1955 that China and Africa truly rediscovered each other (Aning \& Lecoutre, 2009).

Beijing's relations with Africa during this period was characterised mainly by a policy of anti-Soviet rhetoric and support for the anti-Portuguese nationalist movements in Angola and Mozambique. China also supported many liberation movements in Africa, and established diplomatic and economic relations with several newly independent African states (Gill, Huang \& Morrison, 2007). This policy formed part and parcel of its wider policy thrust to boost its political influence globally and expand the "One China" principle which was to diplomatically isolate Taiwan. In response, African states also reciprocated by providing 


\section{AFRICAN \\ EAST-ASIAN \\ AFFAIRS \\ THE CHINA MONITOR}

diplomatic support to China to replace Taiwan in the United Nations Security Council (UNSC) in 1971 (Chau, 2007). China's foreign policy towards Africa during this period was underpinned by five basic principles, namely, mutual respect for sovereignty and territorial integrity; mutual non-aggression; non-interference in each other's internal affairs; equality and mutual benefit; and peaceful co-existence (Hellström, 2009). These principles continue to shape China's policy towards Africa today. For many African countries, China is more appealing than many Western countries due, in particular, to its non-interference policy, as it seems to be an alternative to the Western economic prescriptions that are marred by aid conditionalities and needless foreign interference that disrupts their national sovereignty (Ayenagbo et al, 2012).

In contrast, China's relations with Africa post-1978 shifted into a relationship in which Chinese investments, mainly in infrastructure, were offered in exchange for African natural resources (Aning \& Aubyn, 2013). After a decade hiatus in the China -Africa relationship, three important events reignited Beijing's interest on the continent. The first was the crisis in China's international relations after the Tiananmen Square incident in June 1989. The incredible expansion of the Chinese economy in the 1990s and 2000s was the second factor. The last factor was the support granted by African leaders to Beijing at the UN in the face of intense criticism by the West of its human rights record (Taylor, 2013). Throughout the 1990s, China-Africa relations grew rapidly and in particular, received a major boost in 2000 when the first session of the triennial Forum for China-Africa Cooperation (FOCAC) summit was held in Beijing ${ }^{2}$. Subsequent FOCAC meetings were held in Addis Ababa, Ethiopia (2003), Beijing, China (2006), and Sharm el-Sheikh, Egypt (2009) and once again in Beijing in 2012. Apart from providing an important multilateral mechanism for forging new commitments and strengthening political ties, the FOCAC meetings have provided opportunities for governments and businesses to strengthen their economic cooperation. Furthermore, it has also promoted diplomatic relations, trade and investments between China and African countries (Thompson, 2005). More importantly, through the various FOCAC agreements since 2000, China has pledged to support 
African peace and security endeavours. The 2006 China's Africa Policy Paper for example indicated that:

China will support the positive efforts by the AU and other African regional organizations and African countries concerned to settle regional conflicts and will provide assistance within our own capacity. It will urge the UN Security Council to pay attention to and help resolve regional conflicts in Africa. It will continue its support to and participation in UN peacekeeping operations in Africa ${ }^{3}$.

While these FOCAC commitments on peace and security are by no means rhetorical, they are rather brief and ambiguous in detail when compared to the commitments on economic relations. This means that though peace and security issues are given some level of attention in Beijing's cooperation with Africa, economic rationales or interests continue to dominate this relationship (Large, 2008). But in reality, China's relations with Africa are more driven by a desire to obtain sources of raw materials and energy for China's ongoing economic growth and for new export markets (Taylor, 2006). Suffice to say that if economic impulse is the dominant motivation inspiring China's safari in Africa, why now the rising interest in African peace and security issues? To unpack this, the next section examines the factors behind Beijing's evolving role in African security issues.

\section{Motivations underpinning China's expanding role in Africa security issues}

Three main interrelated factors appear to inspire Beijing's expanding role in African security issues. The first is that China has numerous investments in especially the energy and mineral extraction sectors across the continent, in countries such as Sudan, Nigeria, Algeria, Zambia, Ethiopia and Kenya. In Sudan, for example, China's National Petroleum Corporation (CNPC) dominates the oil sector with an investment which is valued to be about $\$ 7$ billion (Hellström, 


\section{AFRICAN \\ EAST-ASIAN \\ AFFAIRS \\ THE CHINA MONITOR}

2009). Other Chinese National Oil Companies such as the China Petroleum \& Chemical Corporation (Sinopec), PetroChina and the China National Offshore Oil Corporation (CNOOC) also have considerable investments in many other African countries (Taylor, 2006). Moreover, in the mineral extraction sector, Chinese companies have been given access to gold mining in Eritrea, manganese in Côte d'Ivoire, Ghana and Gabon, bauxite in Guinea, titanium in Kenya, uranium in Niger, chromium in South Africa, copper in Zambia, coal and platinum mines in Zimbabwe (Hellström, 2009). Increasingly, most of these investments have come under serious threat due to conflicts and political instability. In Ghana for example, since 2011, there have been several violent clashes between local mining communities and small -scale Chinese miners who are often accused of illegal gold mining activities known in Ghana as 'galamsey'; such activities have also caused huge environmental destruction to farmlands and rivers through the use of heavy machinery, bulldozers and pay loaders (Aning \& Aubyn, 2013, op. cit. Bax, 2011). This led to the deportation of some 38 Chinese in September 2012 from Ghana who were alleged to have been involved in illegal gold mining (Nsiah \& Kodie, 2012). Similar incidences have also occurred in several other West African countries and other African countries such as Kenya, Sudan, Angola and Zimbabwe. Therefore, in order to protect and safeguard its commercial interest and investments, Beijing has inevitably been forced to take a keen interest in the stability and development of those countries where its companies have invested. This partly explains why in certain conflict situations, like that of Sudan where its interests were at stake, China had to be flexible on its dogma of state sovereignty and non-interference to the extent that, it had to publicly encourage Khartoum to allow UN peacekeepers into Darfur (Aning \& Lecoutre, 2009, op. cit. Large, 2007).

The next important factor is that Africa is a major market for Chinese manufactured goods such as textiles, clothing, consumer goods and machine tools and at the same time, the import market of energy (oil) and raw materials such as minerals (copper, bauxite, uranium, aluminium, manganese, iron ore), precious stones, timber, cotton, and fish products (Rotberg, 2008). For this reason, securing markets for Chinese 
goods and the supply of raw materials from Africa for China's manufacturing companies has been a major priority in Beijing's engagement with the continent. Furthermore, China is currently Africa's largest bilateral trading partner and during the past decade, trade between China and Africa has increased more than six-fold. It is therefore clear that without growing prosperity on the African continent, the supply of energy resources and raw materials will be seriously affected and African markets will never meet their full potential for Chinese goods and products. Trade between Africa and China would also be hampered. As a result, any form of armed violence and conflicts on the continent will arguably have implications for its domestic growth rate and development. Accordingly, upholding African security is a way of enhancing China's own domestic development as stability in Africa means a secure market for Chinese goods and investment as well as raw materials and energy imports (Rotberg, 2008).

Beijing's broader foreign policy goal of expanding its political spheres of influence and wish to be seen as a responsible global power who is contributing to international public good of maintaining peace and security is also accountable for its somewhat active role in African security (Saferworld, 2011). That is to say, China's interest in African security issues is also motivated by its global ambitions of being recognized as a significant power on the world stage. For example, apart from contribution to UN peacekeeping operations in Africa, China's participation in anti-piracy efforts in the Gulf of Aden is symptomatic of this assertion (Kostecka, 2010). Though some scholars would argue that China's involvement in the Gulf of Aden was motivated by geo-politics and the protection of national interests, it also shows its willingness to share the burden of upholding international peace and security as a responsible big power (Saferworld, 2011).

\section{China's contributions towards African peace and security: gains and limi- tations}

This section examines some of the gains and limitations of China's security en- 


\section{AFRICAN \\ EAST-ASIAN \\ AFFAIRS \\ THE CHINA MONITOR}

gagements with Africa at the multilateral level of the UN, regional level of the AU and at the Sub-regional level of the Regional Economic Communities.

\section{Multi-lateral level initiatives at the $U N$}

At the multilateral level, China has exhibited greater commitment to peacekeeping activities by increasing its participation in UN operations and peacebuilding efforts as well as providing diplomatic support to African countries during debates at the United Nations Security Council (UNSC) (Saferworld, 2011, op. cit. Davies, 2008). With respect to peacekeeping, China's efforts in Africa have since the 1990s steadily evolved from a position of unwilling participation to one of active engagement due to its strict adherence to principles of state sovereignty, non-intervention, consent of host state before peacekeeping deployment and the non-use of force other than in self-defence 4 . However, in recent times, China's position on these principles has become more flexible and less conservative due to the recognition that traditional peacekeeping is ill-suited to contemporary conflicts (Ayenagbo, et al, 2012, op. cit. Saferworld, 2011). Since its first participation in the UN Transition Assistance Group (UNTAG) in Namibia in 1989, China has deployed its personnel to African countries such as Liberia, Sierra Leone, Democratic Republic of Congo (DRC), Burundi, Sudan, Western Sahara, Cote d'Ivoire and Mozambique. Although the number of Chinese Peacekeepers in Africa cannot be compared to that of Pakistan, Bangladesh and India, it ranks as the largest contributor ${ }^{5}$ among the five permanent members of the UNSC and also the seventh highest provider of assessed contributions (3.93\%) to UN peacekeeping operations as of February 2012 (United Nations Department of Peacekeeping Operations, 2013). This is particularly significant at a time when Western countries are unwilling to deploy personnel to peacekeeping missions in Africa. Beyond these contributions, China as a permanent member of the UNSC has also played a very significant role in the decision-making process with regards to the deployment of peacekeepers to Africa. Beijing has also put greater emphasis at the UNSC on the need for improved cooperation between the UN and African regional/sub-regional organisations towards the maintenance of international peace and 
security. In China's Africa Policy Paper for example, China urged the UN Security Council to pay attention to, and help resolve, regional conflicts in Africa. On the issue of UN reforms, China has also called on the UNSC to give priority to increasing the representation of developing countries, in particular those in Africa. On the diplomatic front, China has sought to represent the interests, positions and concerns of African regional organisations through its permanent seat at the UNSC. A good example of this was China's support to the AU's opposition to the International Criminal Court's (ICC) arrest warrant against President OmarAl-Bashir of Sudan at the UNSC. However, some critics assert that China was only using its position at the UNSC to protect partner regimes and its economic interests in Sudan and moreover, obstructing international action on an urgent situation ${ }^{6}$.

\section{Continental level initiatives: China and the African Union}

China has traditionally adopted a state-centric approach towards each African country governed by principles of state sovereignty and non-interference instead of a one-size-fits-all approach to the whole of Africa (Aning \& Lecoutre, 2009, op. cit. Saferworld, 2011). However, the past five years has seen a deepening cooperation between China and regional organizations such as the AU, which are largely centred on conflict management and resolution primarily through offering support to peacekeeping, humanitarian and mediation efforts. The most visible aspect of this growing partnership is perhaps the new $\$ 200 \mathrm{~m}(£ 127 \mathrm{~m})$ AU headquarters in Addis Ababa, Ethiopia, that was donated by the Chinese government in January 2012 (BBC News, 2013). China has been very instrumental in supporting the AU as it seeks to find African solutions to African problems. It has, through the provision of both material and financial assistance to the AU, supported the implementation of the African Union Peace and Security Architecture (APSA) ${ }^{7}$.

In particular, China has supported AU peacekeeping activities in Sudan [AU Mission in Sudan (AMIS) and UN/AU mission in Darfur (UNAMID)], Somalia 


\section{AFRICAN \\ EAST-ASIAN \\ AFFAIRS \\ THE CHINA MONITOR}

[AU Mission in Somalia (AMISOM)] and also assisted in the development of the African Standby Force (ASF). In 2010 for example, China provided $\$ 1.32$ million to the AU of which a portion was specifically intended for AMISOM (African Union Commission, 2010). Again, in 2011, China provided equipment and material valued at about US\$4.5 million for AMISOM (African Union Commission, 2010). Although these are paltry sums, Beijing has over the years shown greater commitment and willingness to support AU efforts in peacekeeping. But unlike other actors, like the European Union (EU), which has specific programmes such as the African Peace Facility, China's assistance to the AU has been given on an ad hoc basis in the form of grants to support specific mediation/ peacekeeping efforts. Thus, in reality, actual support has been context specific and limited, in that whether China engages with any African country depends on the internal dynamics and economic strength of the country. The support to AMIS was a graphic case in point where China provided one of its greatest ever sums, of $\$ 3.5$ million, to AU in 2006. Apart from the financial contribution, it also sent five batches of humanitarian aid to Darfur in 2004 worth $\$ 5.2$ million, consisting of cross-country vehicles, ambulances, medical instruments and mobile houses ${ }^{8}$.

\section{China and the regional economic communities in Africa}

In its dealing with the RECs in Africa, China has prioritized economic over security issues. For that reason, its relations with the RECs in terms of peace and security have been very restricted. Beijing's relation with the RECs is now expanding and gradually taking shape. But this notwithstanding, China has supported conflict prevention, management and resolution mechanisms of RECs such as the Economic Community of West African States (ECOWAS), South African Development Community (SADC) and Common Market for Eastern and Southern Africa (COMESA). Regarding ECOWAS, for example, China contributed an amount of U.S $\$ 100,000$ to the ECOWAS Peace fund in $2008^{9}$. In 2005, China appointed representatives to SADC, ECOWAS and the AU, signifying its burgeoning relationship with these organizations. Diplomatically, China has also aligned with the positions of RECs at the 
UNSC. A typical case was in 2008 when China and the Russian Federation vetoed UNSC's measures intended to impose sanctions against Zimbabwe's President Robert Mugabe and 13 other Government and security officials considered responsible for the violent crisis in the country. China supported the offices of SADC and the AU, and called upon all parties not to take any action that might have a negative impact on the situation (UNSC Department of Public Information, 2008).

\section{National level engagements}

At the national or bilateral level, which has been the traditional model of China's cooperation with Africa, it has fostered military-related technological exchanges and cooperation with a number of African countries such as Guinea, Sudan and the Democratic Republic of Congo (DRC) (Ayenagbo et al, 2012, op. cit. Saferworld, 2011). It has provided de-mining and intelligence gathering support to African armies, helped train African military personnel and supported the construction of defence and army buildings of African countries (MFA-PRC, 2006). However, one area of grave concern is the secrecy surrounding these forms of military cooperation and the impact of the training programs on the work of African military personnel. This is because some Chinese-trained military personnel have in the past been chided for unprofessional conduct and others implicated in various violations of international humanitarian law (Saferworld, 2011, op. cit. Aning \& Aubyn, 2013). In 2009 for example, Chinese-trained commandos in Guinea were involved in the killing of 150 protesters (Saferworld, 2011). These shortfalls thus raise questions as to how China can ensure that its military assistance is delivered in a more transparent and effective manner and also targeted towards making African military more accountable to civilian authority.

\section{China-Africa security relations and the policy of non-interference}

China's role in African security issues has been guided by one key principle, 


\section{AFRICAN \\ EAST-ASIAN \\ AFFAIRS \\ THE CHINA MONITOR}

non-interference, which it deems as the internal affairs of other states. This is because the Chinese government itself does not allow interference in its own domestic affairs. The Chinese government advocates that national governments alone should be the focus on matters relating to domestic political, economic or social affairs. It was designed in the 1950s to reach out to non-communist states in Asia and to reflect solidarity with newly independent states in Africa, with an emphasis on territorial sovereignty defined in the most rigid and traditional Westphalian terms (Iyasu, 2012). Although the policy of non-interference applies to military interventions and regime change, the principle has been China's modus-operandi in its investment and economic interactions with Africa (Iyasu, 2012). For most African countries, the policy of non-interference seems to be one of the more attractive factors in their partnership with China (Ayenagbo et al, 2012). However, there are growing concerns that the policy is merely to benefit Chinese business and investment interests in Africa as it largely overlooks realities of contemporary conflicts and socio-political realities on the continent. This is because in practical terms, the application of the policy has been tailored to suit Chinese interest wherever it is at stake on the continent.

In Sudan for example, which is one of China's key trading partners and oil suppliers in Africa, despite Chinese claims of non-interference policy, it was involved in the domestic affairs of the country to primarily protect its economic interests. China supplied the Sudanese government with arms and weaponry even when the Darfur crisis was still ongoing. In fact, most of these arms were used for persistent and systematic violations of human rights by government and rebel forces. The supply of arms to the government of Sudan for example, indicated a paradigm shift in China's noninterference foreign policy (Ferim, 2013). This ambiguity raises important questions about what some scholars have referred to as China's neo-imperialist ambitions on the continent. Again, when the UNSC resolved to pass a resolution that mandated sanctions against the Sudanese government and intervention by a UN force to end the Darfur crises, instead of voting "no" and vetoing such intervention which is germane to its non-interference policy, it rather abstained from voting (Saferworld (2011). China's position only changed later on when it accepted the necessity of in- 
ternational action by supporting UNSC Resolution 1769 which created the AUUN hybrid mission in Darfur (UNAMID). The role of China in the Sudanese case for example, reinforced the perception that it supports partner regimes in order to protect its economic interests. Similarly, the Libya crises also had negative consequences on China's economic interests, causing Beijing to modify its policy of non-interference. That is, although Beijing expressed grave reservations over the North Atlantic Treaty Organization (NATO) campaign, it chose not to use its veto to block the intervention. Instead, it abstained when Resolution 1973 was passed to impose a no-fly zone and to authorize all measures necessary to protect civilians, though it supported UNSC to impose an asset freeze, travel ban and arms embargo against Gaddafi's regime (Hughes, 2012). Clearly, China's adoption of a flexible and pragmatic approach in its diplomatic stance on Libya was arguably to protect its economic interests in the country which was contrary to its principle of non-interference in other countries' domestic affairs.

Clearly, the role of China in Sudan and Libya, especially as discussed above, suggests that in reality non-interference does not mean that China sits back and watches or that non-interference equals indifference. Beijing has adopted a flexible approach in its implementation of the policy, usually allowing China to protect its interests wherever it is at stake on the continent. This however, raises important questions as to whether China's long-standing dogma of noninterference in the domestic affairs of other states is still relevant today. The effect of the policy is that it has allowed China to "stay silent" in times of crises in Africa or wait for other nations especially Western countries to interfere ${ }^{10}$. This has in some cases obstructed urgent international action in crises situations on the continent. Other scholars have also criticized Beijing of reaping the benefits of peace and security underwritten by its co-members at UNSC because of its sometimes minimal involvement in the resolution of crises on the continent. Given China's current status as a global power and its increasing investments on the continent, Beijing needs to redefine its non-interference policy and actively 


\section{AFRICAN \\ EAST-ASIAN \\ AFFAIRS \\ THE CHINA MONITOR}

participate in the resolution and management of African security issues. Currently, there are debates ongoing within China on this issue. One of such discussion has centred on academic Wang Yizhou's notion of "creative involvement" as a replacement for "non-interference (Zhou, 2011)." The notion of "creative involvement" calls for China's active participation in international Affairs instead of intervention by force. Thus, it calls for an adjustment of attitude and new diplomatic methods which should focus on the use of cautious, creative and constructive mediation when dealing with international issues (Zhou, 2011). Indeed, this notion is not in opposition to the Chinese principle of non-interference or traditional diplomatic principles, but rather an enrichment of these principles.

\section{Some recommended future policy directions}

There is no doubt that the policy of non-interference was a practical model when China's economic interaction with Africa and the rest of the world was negligible. However, with regards to growing investments, political interests and power on the global stage, China needs to acknowledge the fact that its policy of non-interference does not fall in line with the realities and challenges of contemporary conflict and political instability on the African continent. In fact, it is antithetical to global norms of the Responsibility to Protect (R2P) and the Responsibility while Protec-ting (RWP) which holds not just states, but also the international community as being responsible for protecting citizens under eminent threat or danger from genocide, war crimes, ethnic cleansing and crimes against humanity (UN General Assembly, 2005). Using its status as a global economic power in addition to its veto power in the UNSC, China needs to play a much greater role in the prevention, management and resolution of African security challenges to establish sustainable peace and stability on the continent. Otherwise, the consequences of conflicts and political instability for Chinese investments and interest in Africa could be extensive. Playing an active role in African security issues would invariably help change the perception that China is purely exploiting African countries and is Africa's new colonial master rather than a development partner. 
Rethinking China's policy of non-interference should not follow the approach of the West which has received immense criticism from African countries and which has driven African states to China in the first place. Rather, the revision of non-interference should mean a balanced act of investment and conflict sensitivity by China and a more robust engagement of Africa beyond the economic sphere $^{11}$. To this end, African countries need to develop a common framework or collective strategy to guide their own dealings with China and insist that China supports the national, regional and continental institutions for peace and security which lacks funding and technical support ${ }^{12}$. That is, African governments need to move from competition among themselves for Chinese investment and work together to identify critical areas of technical and financial difficulties where China can support. But most importantly, African countries need to bear in mind that they have the primary responsibility in strengthening their domestic as well as regional institutions of peace and security. Apart from supporting African peace and security, China should also make a concerted effort to ensure that its investments are not fuelling conflict and undermining peace and security in the continent.

\section{China and other external actors in Africa: toward a more co-operative ap- proach}

Indisputably, the heightened engagement of China in Africa has important implications for other actors on the continent such as the US, European Union, Brazil, Japan, Canada, Australia and India. Generally, there have been longstanding suspicions among these actors, fostered in part by different philosophies and approaches towards governance and sometimes a clash of interests on the continent. For example, one problematic issue between China and the West is that of promoting good governance, transparency and human rights in connection with development aid (Thompson, 2005). Thus, while the West and their institutions such as the International Monetary Fund (IMF) link development aid to the promotion of political transparency and good governance in African coun- 


\section{AFRICAN \\ EAST-ASIAN \\ AFFAIRS \\ THE CHINA MONITOR}

tries, Chinese aid comes with no strings attached except the 'One China' principle and tying aid and loans to Chinese Companies and materials. For this reason, China, for instance, ignored Western sanctions against Sudan and Zimbabwe and continued to be one of the most important suppliers of military equipment to both countries. Moreover, some Western countries have also criticized China's non-interference policy of allowing it to "stay silent" in times of crises in Africa, or wait until other nations interfere and later reaping the benefits of peace and security underwritten by its co-members at $\mathrm{UNSC}^{13}$. In other words, China is unable to take a firm stance and reach resolutions on matters relating peace and security in Africa.

China and the West also differ in terms of the interpretation and application of UN peacekeeping normative principles such as the use of force except in self-defence and defence of the mandate. China has concerns about robust peacekeeping interventions that go beyond UNSC mandates. That is, Beijing has persistently cautioned the West's use of civilian protection mandates as a façade for other political agendas, such as regime change and pursuing other ulterior motives and agendas (Bellamy \& Williams, 2005). This was particularly the case during the Libyan crises when China and other members of the UNSC became sceptical about the motives behind the use of force that was being advocated by some Western countries. China's scepticism was premised on its long-established 'five principle foreign policy' which emphasizes non-interference and steering away from using force.

In spite of these differences in approach, China and other external actors, especially the US, frequently fail to distinguish areas where they can cooperate and work together for the mutual benefit of Africa. China and the US, for example, can ensure that African security issues take a higher priority in their relations. To this end, trilateral dialogues such as China-Africa-US forums can be initiated to allow for frequent exchanges of views and perspectives on security issues concerning Africa. Though this proposal is difficult to achieve, it can be explored. This cooperative effort can also be extended to other sectors such as economic and political relations. Collaboration between China and the US will help, for instance, to address differences in ap- 
proaches to conflict prevention, management and resolutions in order to increase mutual understanding and gradually build consensus around key norms and international best practices. For example, in the protection of civilians, Chinese and US policy makers can compare different policy approaches and start to develop consensus around best international practices. Furthermore, while the assistance of the West explicitly seeks to improve governance and generate political reforms in post-conflict countries, China does not share the same liberal norms as it rather prefers economic development to post-conflict reconstruction $^{14}$. Building consensus around some of these diverse approaches can also serve as an entry point through which both China and the West can cooperate more extensively to promote peace and security in Africa. But it is important that Africa plays a more proactive role in shaping and directing any cooperation between China and the West, as well as setting the priorities for such cooperative efforts and initiatives ${ }^{15}$. For instance, in areas of disagreement and tensions between China and the West, such as issues of governance, human rights, and environmental standards, Africa can facilitate debates and dialogue among them and create a greater African voice. This is imperative because African leadership on such contentious issues can help harness cooperation in a more constructive way to the ultimate benefit of the continent.

\section{Endnotes}

1. The Non-Aligned Movement (NAM) consist of states that were not formally aligned with neither the Western or Eastern bloc during the Cold War period. It was formed to ensure the national independence, sovereignty, territorial integrity and security of non-aligned countries in their struggle against imperialism, colonialism, neo-colonialism, racism, and all forms of foreign aggression, domination, and interference.

2. This conference involved more than 80 ministers from China and 44 African 


\section{AFRICAN \\ EAST-ASIAN AFFAIRS

countries together with representatives from international organisation and business communities.

3. See 'China's African Policy' January 2006

4. On this point, it would be recalled that the changes of post-Cold-War conflicts from inter-state to intra-state conflicts led to a paradigm shift in the way UN operation was conceptualized. As a result, in certain conflict situations like Liberia in the early 1990s, which highlighted the need for rapid, early and robust intervention, the use of force under Chapter VII of the UN Charter was evoked to forestall peace in the country. But China unlike its Western counterparts had strong views against such interventions as it placed strains upon China's core principle of non-interference in the internal affairs of other countries.

5. China ranks 16th (with personnel of 1,870 ) out of 113 police and military contributing countries to UN peacekeeping operations. See the UN DPKO (2012) 'Ranking of Military and Police Contributions to UN Operations' Month of Report: 30 November 2012.

6. Saferworld, (2011), op. cit.

7. The APSA gives the AU the necessary instruments to achieve not only the objectives of its Constitutive Act, but also the tasks set out in the Protocol that establishes the AU's Peace and Security Council (PSC). Some of these tasks as set out in the PSC Protocol include among other things: mechanisms for conflict prevention, early warning and preventive diplomacy, peace-making, peacebuilding and peacekeeping, promotion of democratic practices, humanitarian action and disaster management. See Protocol Relating to the Establishment of the Peace and Security Council (PSC), 2002.

8. Ayenagbo, et al (2012), op. cit.

9. Saferworld, (2011), op. cit. 
10. See Iyasu, (2012), Iyasu, A.A. 2012. China's non-Interference policy and rising African concerns.

11. See Iyasu, (2012), op. cit.;

12. See Iyasu, (2012), op. cit.;

13. See Iyasu, (2012), op. cit.;

14. Saferworld, (2011), op. cit.

15. Aning, K. and Aubyn, F. 2013. "From Scepticism to Active Engagement:

Negotiating China's Role in African Peace and Security". Unpublished paper.

\section{Bibliography}

African Union Commission. 2010. "AU Commission Receives Important Financial Donation from China" [Press Release]. 29 November 2010.

Bax, P. 2012. Ghana's Gold Sparks Conflict with Illegal Chinese Miners, [Online]. Available: http://www.bloomberg.com [2012, March 27].

Large, D. 2007. Arms, oil, and Darfur: The Evolution of Relations between China and Sudan', Sudan Issue Brief, Small Arms Survey, [Online]. Available: http://www.smallarmssurvey.org-Sudan [2013, April 1].

Aning, K. and Aubyn, F. 2013. "From Scepticism to Active Engagement: Negotiating China's Role in African Peace and Security". Unpublished paper.

Ayenagbo, K., Njobvu, T., Sossou, V.J. and Tozoun, B.K. 2012. China's peacekeeping operations in Africa: From unwilling participation to responsible contribution. African Journal of Political Science and International Relations, 6(2):22-32. 


\section{AFRICAN \\ EAST-ASIAN \\ AFFAIRS \\ THE CHINA MONITOR}

BBC News. 2013. African Union opens Chinese-funded HQ in Ethiopia, [Online]. Available: http://www.bbc.co.uk/news/world-africa-16770932 [2013, March 29].

Bellamy, A.J. and Williams, P.D. 2005. The Responsibility to Protect and the Crises in Darfur. Security Dialogue, 36:27.

Bellamy, A.J. and Williams, P.D. 2011. The New Politics of Protection: Cote D'Ivoire, Libya and the Responsibility to Protect. International Affairs.

Chau, C. 2007. Political Warfare In Sub-Saharan Africa: U.S. Capabilities and Chinese Operations in Ethiopia, Kenya, Nigeria, And South Africa [Online]. Available: http://www.StrategicStudiesInstitute.army.mil/ [2013, April 5].

Ferim, V. The Ambiguity of China's Non-Interference Policy as A drawback to Peace and Stability in the Sudan [Online]. Available: http:// www.academia.edu [2013, April 12].

Gill, B., Huang, C. and Morrison, J.S. 2007. Assessing China's Growing Influence in Africa. China Security, 3(3):4-5.

Hellström, J. 2009. China's emerging role in Africa: A strategic overview. FOI Studies in African Security. Available: http://www.foi.se/africa [2013, April 10].

Hughes, C.R. 2012. USAK Analysis: The Libya Crisis and Challenges to China's Non-Interference Principle [Online]. Available: http://www.usak.org [2013, April 15].

Iyasu, A.A. 2012. China's non-Interference policy and rising African concerns.

Kostecka, D. 2010. The Chinese Navy's Emerging Support Network in the Indian Ocean. China Brief, 10(15).

Large, D. 2008. China's role in the mediation and resolution of conflict in Africa' Background Paper for The OSLO Forum of Network Mediators. Centre for 
Humanitarian Dialogue.

Ministry of Foreign Affairs of the People's Republic of China (MFA-PRC). 2006. China's African Policy. January 2006.

Nsiah, H. and Kodie, K.A. 2012. Attacks on Chinese: Too Sad! [Online]. Available: http:// www. myjoyonline.com [2012, December 28].

Rotberg, R. 2008. China's Quest for Resources, Opportunities, and Influence in Africa in Rotberg, R. (ed.). China into Africa: Trade, Aid, and Influence. Cambridge: Brookings.

Saferworld. 2011. China's growing role in African peace and security. Saferworld, Report. January 2011.

Taylor, I. 2006. Unpacking China's Resource Diplomacy in Africa. Center on China's Transnational Relations, Working Paper No. 19.

Taylor, I. 2013. The On-going Development of Chinese Ties with Sub-Saharan Africa. Europa World.

Taylor, I. 1998. China's Foreign Policy Towards Africa in the 1990s. Journal of Modern African Studies, 36(3):443-460.

Thompson, D. 2005. China's Emerging Interests in Africa: Opportunities and Challenges for Africa and the United States. African Renaissance Journal, pp.20-21.UN General Assembly. 2005. 2005 summit Outcome, A/60/1. para. 138-40; Alex J. Bellamy and Paul D. Williams, (2011) 'the New Politics of Protection: Cote D'Ivoire, Libya and the Responsibility to Protect' International Affairs.

United Nations Department of Peacekeeping Operations. 2013. UN Mission's Summary detailed by Country's Month of Report: February 2012. 


\section{AFRICAN \\ EAST-ASIAN \\ AFFAIRS \\ THE CHINA MONITOR}

Issue 3

September 2013

UNSC Department of Public Information. 2008. Security Council Fails to Adopt Sanctions Against Zimbabwe Leadership As Two Permanent Members Cast Negative Votes [11 July 2008].

Zhou, W.Y. 2011. Creativity involved in China's new diplomatic approach. Peking: Peking University Press. 